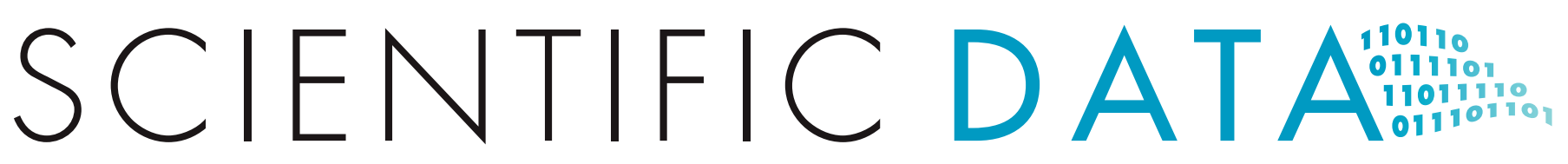

\title{
OPEN Corrigendum: A database of marine phytoplankton abundance, biomass and species composition in Australian waters
}

Claire H. Davies, Alex Coughlan, Gustaaf Hallegraeff, Penelope Ajani, Linda Armbrecht, Natalia Atkins, Prudence Bonham, Steve Brett, Richard Brinkman, Michele Burford, Lesley Clementson, Peter Coad, Frank Coman, Diana Davies, Jocelyn Dela-Cruz, Michelle Devlin, Steven Edgar, Ruth Eriksen, Miles Furnas, Christel Hassler, David Hill, Michael Holmes, Tim Ingleton, Ian Jameson, Sophie C. Leterme, Christian Lønborg, James McLaughlin, Felicity McEnnulty, A. David McKinnon, Margaret Miller, Shauna Murray, Sasi Nayar, Renee Patten, Sarah A. Pausina, Tim Pritchard, Roger Proctor, Diane Purcell-Meyerink, Eric Raes, David Rissik, Jason Ruszczyk, Anita Slotwinski, Kerrie M. Swadling, Katherine Tattersall, Peter Thompson, Paul Thomson, Mark Tonks, Thomas W. Trull, Julian Uribe-Palomino, Anya M. Waite, Rouna Yauwenas, Anthony Zammit \& Anthony J. Richardson

Scientific Data 3:160043 doi:10.1038/sdata.2016.43 (2016); Published 21 Jun 2016; Updated 6 Dec 2016

A series of errors in our database were brought to our attention by readers, and have been corrected in an updated version of this database, which is accessible via the AODN at the following link: https://portal.aodn.org.au/search?uuid = 75f4f1fc-bee3-4498-ab71-aa1ab29ab2c0.

The custodian details of several datasets were incorrect. These fields in the metadata table have been updated to correctly assign P744, P746, P748, and P778 to the Australian Antarctic Division, and P752 to the Royal Belgian Institute of Natural Sciences.

Species names and functional group assignments have been changed for a small number of records to fix identified errors. Tripos brevis and Tripos arietinus were spelt incorrectly, and have been duly corrected. Pedinellaceae was wrongly assigned to dinoflagellate as a functional group, and has now been re-assigned to flagellate. The 'Naked flagellate' group has been renamed 'Flagellate' as there is some inconsistency in the use of the term 'Naked flagellate' and what precisely would be included. The functional group 'Other', has also been excluded as this contained data that was not necessarily phytoplankton but had been found in phytoplankton counts. The macroalgae Murrayella australica, Cladophora spp., Chlorohormidium sp., Eudorina spp., Tribonema spp., Chlorohormidium spp. were also removed.

In addition to these corrections, three datasets have been extended to include more recently acquired data: P 597 IMOS Australian Continuous Plankton Recorder survey (ongoing dataset, 59089 new records as of 2016-08-31); P599 IMOS National Reference Stations (ongoing dataset, 14669 new records as of 2016-08-31); and P1068 Great Barrier Reef Expedition 1928-29 (new dataset, 1340 new records). Table 1 provides a summary of the overall change in database contents. 


\begin{tabular}{|l|c|c|}
\hline Total records & Original & Version 1 \\
\hline Presence/Abundance records & 222617 & 224262 \\
\hline Species level & 123931 & 125959 \\
\hline Genera level & 78153 & 78921 \\
\hline Higher level & 20533 & 19382 \\
\hline Absence records & 3399230 & 3499959 \\
\hline Total records & 3621847 & 3724221 \\
\hline Taxa at species level & 1499 & 1530 \\
\hline Taxa at genera level & 522 & 512 \\
\hline Higher level taxa & 107 & 89 \\
\hline
\end{tabular}

Table 1. Summary of database contents.

This dataset will continue to grow and will be regularly updated with new data and any further corrections to the data. Users can email imos-plankton@csiro.au with any comments, which will be reviewed and included in future updates if applicable. The AODN portal will always direct the user to the most recent version, the original version will remain available at http://dx.doi.org/10.4225/69/ 56454 b2ba2f79, and interim versions will be available on request.

(c) This work is licensed under a Creative Commons Attribution 4.0 International License. The images or other third party material in this article are included in the article's Creative Commons license, unless indicated otherwise in the credit line; if the material is not included under the Creative Commons license, users will need to obtain permission from the license holder to reproduce the material. To view a copy of this license, visit http://creativecommons.org/licenses/by/4.0

(C) The Author(s) 2016 


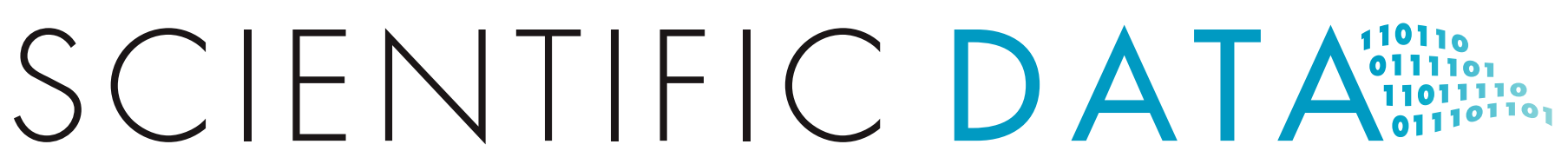

\section{Corrigendum: A database of marine phytoplankton abundance, biomass and species composition in Australian waters}

Claire H. Davies, Alex Coughlan, Gustaaf Hallegraeff, Penelope Ajani, Linda Armbrecht, Natalia Atkins, Prudence Bonham, Steve Brett, Richard Brinkman, Michele Burford, Lesley Clementson, Peter Coad, Frank Coman, Diana Davies, Jocelyn Dela-Cruz, Michelle Devlin, Steven Edgar, Ruth Eriksen, Miles Furnas, Christel Hassler, David Hill, Michael Holmes, Tim Ingleton, Ian Jameson, Sophie C. Leterme, Christian Lønborg, James McLaughlin, Felicity McEnnulty, A. David McKinnon, Margaret Miller, Shauna Murray, Sasi Nayar, Renee Patten, Sarah A. Pausina, Tim Pritchard, Roger Proctor, Diane Purcell-Meyerink, Eric Raes, David Rissik, Jason Ruszczyk, Anita Slotwinski, Kerrie M. Swadling, Katherine Tattersall, Peter Thompson, Paul Thomson, Mark Tonks, Thomas W. Trull, Julian Uribe-Palomino, Anya M. Waite, Rouna Yauwenas, Anthony Zammit \& Anthony J. Richardson

Scientific Data 3:160043 doi:10.1038/sdata.2016.43 (2016); Published 21 Jun 2016; Updated 11 April 2017

The authors regret that Sarah A. Pausina was omitted in error from the author list of the original version of this Data Descriptor. This omission has now been corrected in the HTML and PDF versions of this Data Descriptor, as well as the accompanying Corrigendum.

Cc) This work is licensed under a Creative Commons Attribution 4.0 International License. The
images or other third party material in this article are included in the article's Creative
Commons license, unless indicated otherwise in the credit line; if the material is not included under the
Creative Commons license, users will need to obtain permission from the license holder to reproduce the
material. To view a copy of this license, visit http://creativecommons.org/licenses/by/4.0

(C) The Author(s) 2017 